å forenkle ryggdiagnostikk. I de nasjonale retningslinjene er det anbefalt samme tredeling som i de europeiske retningslinjene $(4,5)$. Derfor står klassifiseringen på trygg grunn. Det er likevel mange med Lie som ønsker å dele inn uspesifikke ryggsmerter i undergrupper. Avanserte metoder brukes for mer nøyaktig inndeling, men verken fasettleddsinjeksjon, diskografi eller MR kan pålitelig diagnostisere smertens lokalisasjon.

Det forskes mye på gener og mellomvirvelskiven, men det har ikke gitt behandlingsmessige konsekvenser (6). Andre gener kan ha betydning for smertesensitivisering uavhengig av lokalisasjon (7).

I de europeiske retningslinjene er pasienter plaget med uspesifikke ryggsmerter $\mathrm{i}>2$ år anbefalt vurdering for avstivningsoperasjon (4). Lie har et godt argument når han kritiserer seleksjon av pasienter for kirurgi på et slikt grunnlag. Pga. lange ventelister for operasjon fikk vi i oppgave å gi alternativ behandling til pasienter med over ett års ventetid på operasjon (8). I fortsettelsen gjennomførte vi randomiserte studier $(2,3)$.

Kirurgi er ingen løsning for de fleste pasienter med vanlige ryggsmerter. Det er vanskelig å velge ut pasienter med spesifikk nytte av operasjon. Kunnskap om ryggsmerter gir ikke grunnlag for å overfokusere på degenerasjon av mellomvirvelskiven. I dag konkluderes det med at både kognitiv atferdsrettet behandling og trening har effekt. Det er dette Håkon Lie kaller ingen behandling, og det er derfor han er bekymret for $85 \%$ av ryggpasientene. Det er ikke grunn til å dele hans bekymring, men forskningen vil søke etter bedre diagnostikk og behandling.

\section{Jens Ivar Brox}

Klinikk for kirurgi og nevrofag

Oslo universitetssykehus

Jens Ivar Brox (f. 1955) er seksjonsoverlege ved Ortopedisk avdeling.

Ingen oppgitte interessekonflikter.

\section{Litteratur}

1. Lie H. Uspesifikke smerter gir uspesifikk behandling. Tidsskr Nor Legeforen 2011; 131: 1987-8.

2. Brox JI, Sorensen R, Friis A et al. Randomized clinical trial of lumbar instrumented fusion and cognitive intervention and exercises in patients with chronic low back pain and disc degeneration. Spine 2003; 28: 1913-21.

3. Hellum C, Johnsen LG, Storheim K et al. Surgery with disc prosthesis versus rehabilitation in patients with low back pain and degenerative disc two year follow-up of randomised study. BMJ 2011; 342: d2786.

4. Airaksinen O, Brox JI, Cedraschi C et al. Chapter 4 . European guidelines for the management of chronic nonspecific low back pain. Eur Spine J 2006; 15 (suppl 2): 192-300.

5. Dagenais S, Haldeman S. Evidence-based management of low back pain. St. Louis, MO: Elsevier 2011.
6. Le Maitre CL, Pockert A, Buttlet DJ et al. Matrix synthesis and degradation in human intervertebra disc degeneration. Biochemical Society Transactions 2007: 35: 652-5.

7. Dai F, Belfer I, Schwartz CE et al. Association of catechol-0-methyltransferase genetic variants with outcome in patients undergoing surgical treatment for lumbar degenerative disc disease. Spine J 2010; 10: 949-57.

8. Brox JI, Friis A, Holm I et al. Pasienter med kronisk degenerativ rygglidelse - kan operasjonskøen reduseres med konservativ behandling? Tidsskr Nor Lægeforen 1999; 119: 1784-7.

\section{Mer åpen dialog om global helse}

I Tidsskriftet nr. 20/2011 skriver utenriksminister Jonas Gahr Støre om «Global helse og utenrikspolitikk» (1). Støre viser at global helse er en prioritet for regjerningen, og utfordrer helsepersonell til dialog og innspill i utviklingen av en langsiktig strategi for å sikre folkehelsen gjennom internasjonale avtaler.

Vi ønsker Støres invitasjon til dialog rundt utenrikspolitikk og helse velkommen, selv om vi i praksis har erfart at det ikke er like åpenbart hvordan vi skal gå i dialog med Utenriksdepartementet. I oktober 2010 startet departementet arbeidet med en stortingsmelding om global helse. Etter lovende dialogmøte og høringsrunde til førsteutkastet ble det stille frem til juni 2011, hvor meldingens foreløpige innhold ble presentert. Imidlertid forelå det ikke skriftlig utkast med mulighet til innspill.

Ved å føre en mer åpen dialog, kunne stortingsmeldingen vært en unik mulighet til økt engasjement, debatt og samarbeid om global helse, ved å dra nytte av kompetansen i norske fagmiljøer og organisasjoner. Vår erfaring er dessverre at arbeidprosessen er blitt mer og mer lukket. Særlig problematisk er det at Utenriksdepartementet ikke er tydelige på hva som legges til grunn $\mathrm{i}$ «det faglige og vitenskapelige grunnlaget for de saker vi fremmer». Vi savner bl.a. redegjørelse for norske politiske prioriteringer innenfor global helse. Hvordan begrunnes vaksinasjonssatsingen versus andre helseutfordringer?

Norsk medisinstudentforening påpekte under første dialogmøte nødvendigheten av koherens i utenrikspolitikken. Utenriksministeren var enig: «studentforeningen peker på noe essensielt: Alt slutter med helse men hvor begynner det? Helse må inn som aspekt $i$ alt vi gjør - nordområdene, handel, væpnet vold, klima, nedrustning - stikkordet er koherens. Politikken skal henge sammen» (2).

Støre ønsker å inkludere helse i debatter hvor den ikke er på agendaen i dag. Sikring av helse gjennom internasjonale avtaler er viktig, men langsiktig verdi av disse avtalene forringes om f.eks. rettigheter i handelsavtaler prioriteres over helsemessige vurderinger. Eksempel på hvordan folkehelsen kan utfordres av uforenlige handels- avtaler er Philip Morris’ søksmål mot Norge (3). En annen utfordring for global helse er finanskriser. Banebrytende tiltak som en global skatt på finanstransaksjoner vil være nødvendig for å beskytte helse og utvikling i vanskelige økonomiske tider. Men da må den politiske viljen for dette være til stede. Som Støre sier, kan Norge i slike saker gå foran og vise at helse kan være et mål for utvikling - $\mathrm{i}$ innenriks- så vel som utenrikspolitikk.

Vi ønsker å ta imot Støres utfordring, og håper at Utenriksdepartementet ønsker å gå inn $\mathrm{i}$ åpnere dialog med oss og andre aktører.

\section{Unni Gopinathan}

Johanne Helene Iversen

Kristine Husøy Onarheim

Norsk medisinstudentforening ( $\mathrm{Nmf}$ )

Unni Gopinathan (f. 1986) er medisinstudent ved Universitetet i Oslo og er medlem av Norsk medisinstudentforening.

Ingen oppgitte interessekonflikter.

Johanne Helene Iversen (f. 1987) er medisinstudent ved Universitetet i Bergen og internasjonalt ansvarlig i Norsk medisinstudentforening.

Ingen oppgitte interessekonflikter.

Kristine Husøy Onarheim (f. 1987) er medisinstudent ved Universitetet i Bergen og har hatt verv i Norsk medisinstudentforening. Ingen oppgitte interessekonflikter.

\section{Litteratur \\ 1. Støre JG. Global helse og utenrikspolitikk. Tidsskr Nor Legeforen 2011; 131: 2092 \\ Referat fra oppstartsmøte med sivilt samfunn om stortingsmelding om global helse i utenriks- og utviklingspolitikken. Utenriksdepartementet, 18.10.2010. www.legeforeningen.no/asset/49921/ 1/49921 1.pdf (1.11.2011). \\ 3. EFTA-domstolen: Forbudet mot synlig tobakk, 12.9.2011. www.lovdata.no/nyhet/2011/ 20110912-2169.html (1.11.2011).}

\section{For mange tidsskrifter?}

Erlend Hem peker i sin lederartikkel på det økende antallet tilgjengelige tidsskrifter som tilbyr «open access»-publisering mot forfatternes betaling (1). Han trekker parallellen til kvaliteten på forskningen, og konkluderer med at den er dårlig, $\mathrm{i}$ beste fall middelmådig, spesielt $\mathrm{i}$ åpent tilgjengelige tidsskrifter, som «ubegrenset tar alt» og hvor utgivere eller redaktører knapt bryr seg om lengde og innhold. Kanskje Hem har rett i noe, men bildet synes å være ganske forenklet. Om forskningskvaliteten ikke er blitt bedre, er det da antallet tilgjengelige tidsskrifter som er problemet?

Samme kvalitetsmål gjelder for alle tidsskrifter - å være registrert i tellesyste- 
mene, indeksert i PubMed/Medline, og å ha høyest mulig impaktfaktor. Kanskje er det sistnevnte som er hovedproblemet (2)? Skal man hevde seg kan man verken ta lett på de redaksjonelle oppgavene, akseptere alt eller ta inn ubegrensede mengder. Egen erfaring med et skandinavisk tidsskrift, brakt fra «grå litteratur» til PubMed og indeksering i Thomson Scientific, viser at det er kun målrettet og bevisst arbeid som holder (3). Antallet refuserte manus ligger på rundt $60 \%$. Første impakfaktor i 2011 var på 2,18, og dermed er dette tidsskriftet rangert blant topp tre i Europa i sitt fagfelt. Man vil finne like stor spredning i kvalitet blant disse tidsskriftene (hos BioMedCentral og Public Library of Science) som i de tradisjonelle forlagene. Noen kommer for å bli og andre legges ned - Darwins lover gjelder også her. De fleste tradisjonelle forlag omgjør en økende andel av sin portefølje til «open access» og bare på nett - papirutgaven er i stor grad ferd med å forsvinne.

Mangfoldet av tilgjengelige tidsskrifter er nødvendig for grasrota - få starter med megastudier i New England Journal of Medicine eller stjernefunn i Science. På veien mot stjernene går imidlertid svingene innom både Tidsskriftet og andre publiseringskilder for de fleste. Det har alltid vært mulig å «dumpe» en studie eller artikkel $i$ et tidsskrift, det har ikke forandret seg med «open access» og nettpublisering. Men tilgjengeligheten er forandret.

Hva som er «god forskning» er et interessant spørsmål. Svaret er nemlig ikke enslydende på tvers av disipliner og fagkretser. Problemet blir ikke da hvor mange tidsskrifter som er tilgjengelig, men hvordan utdanne gode forskere som kan stille de riktige spørsmålene med de beste metodene? Og, hvilke metoder har vi for anerkjennelse av forskning generelt, og klinisk forskning spesielt? Trenger vi en ny valuta for å måle og kreditere klinisk forskning (2)? Om tidsskriftene er budbringere, så er det da oppdragsgiverne som må øke sin innsats for å dyrke frem de flinke talentene, de gode metodene og tilstrekkelige midler for å gjennomføre de riktige prosjektene. Det koster mer enn «open access».

\section{Kjetil Søreide}

Stavanger universitetssjukehus

Kjetil Søreide (f. 1977), lege ved Gastrokirurgisk seksjon, Avdeling for kirurgi, Stavanger universitetssjukehus, og professor II ved Institutt for kirurgiske fag, Universitetet i Bergen. Han er redaktør i British Journal of Surgery og i Scandinavian Journal of Trauma Resuscitation and Emergency Medicine.

Oppgitte interessekonflikter: Forfatteren har mottatt honorar fra Scandinavian Journal of Trauma Resuscitation and Emergency Medicine og British Journal of Surgery.
Litteratur

1. Hem E. For mange tidsskrifter - for lite god forsk ning. Tidsskr Nor Legeforen 2011; 131 : 1871.

Büchler MW, Diener MK, Weitz J. Scientific evaluation of modern clinical research: we need a new currency! Langenbecks Arch Surg 2011: 396 : 937-9.

3. Lossius HM, Søreide K. Open access publishing: a girder in the success of the Scandinavian Journa of Trauma, Resuscitation and Emergency Medicine. Scand J Trauma Resusc Emerg Med 2011 cine. $19: 7$.

\section{For mange tidsskrifter - for lidt god forskning?}

I Tidsskriftet nr. 19/2011 skrev Erlend Hem en interessant leder om de nye elektroniske tidsskrifter (1). Han skriver, at han endnu ikke har fået afvist en artikel i et elektronisk tidsskrift, og til det må man selvfølgelig gratulere. Jeg hører til i en anden gruppe, hvor jeg flere gange har fået afvist artikler i de elektroniske tidsskrifter. For nylig afviste BMC Anesthesiology en af vores artikler, og de anbefalede så, at vi sendte den til BMC Research Notes, som helt sikkert ville tage den. BMC Research Notes afviste den dog også. En anden artikel fra min gruppe blev for nylig afvist af $P L o S$ Medicine. Så påstanden om, at de elektroniske tidsskrifter publicerer alt hvad de får, blot for at øge profitten, er ikke korrekt. Mange af de elektroniske tidsskrifter har også en impact factor (PLoS Medicine = 15,6), som skal plejes, så selvfølgelig foregår der en relevant og grundig kvalitetsvurdering i samtlige redaktioner. At påstå det modsatte er ikke fair overfor de hårdt arbejdende redaktører og bedømmere.

Erlend Hem skriver, at man i de elektroniske tidsskrifter accepterer mange manus pga. den elektroniske publiceringsform, hvor omkostningerne skulle være næsten nul. Dette er ikke korrekt. Alle elektroniske tidsskrifter har også sidebudgetter, hvor der er omkostninger til redaktion, sprogbehandling og sats samt web-relaterede udgifter. Det eneste man sparer er papir og porto.

Jeg er bl.a. redaktør for Danish Medical Bulletin, som er et elektronisk tidsskrift og open access, dvs. gratis at læse. Financiering af omkostningerne kommer fra den danske lægeforening (dvs. medlemskontingent) og fra publiceringsgebyr fra udenlandske forfattere. Dvs. danske forfattere betaler ikke publiceringsgebyr, hvis de er medlem af lægeforeningen. Og jeg kan på det kraftigste garantere, at kvalitetsvurderingen af artikler fra udlandet er fuldstændig den samme som for de danske forfattere. Man kan ikke være redaktør og så se bort fra de normale kriterier for accept/ publikation af en artikel.

Erlend Hem antyder, at interesserne for tidsskriftets ejere går frem for interesserne for redaktøren. Dette er imod Vancouvergruppens retningslinjer (2), hvor man netop betoner «editorial freedom» som noget helt centralt. Hvis man er redaktør og går på kompromis med kvaliteten udelukkende pga. et økonomisk pres fra tidsskriftets ejere, så bør man finde sig et andet job.

\section{Jacob Rosenberg \\ Ugeskrift for Læger}

København

Jacob Rosenberg (f.1964) er professor, dr.med. og redaktør for Ugeskrift for Læger og Danish Medical Bulletin.

Ingen oppgitte interessekonflikter.

\section{Litteratur \\ Hem E. For mange tidsskrifter - for lite god forsk ning. Tidsskr Nor Legeforen 2011; 131: 1871. \\ 2. ICMJE International Committee of Medical Journa Editors. Uniform -requirements for manuscripts: editorship. www.icmje.org/ethical_2editor.html (3.11. 2011) \\ Alle forskningsresultater bør publiseres}

I Tidsskriftet nr. 19/2011 uttrykker Erlend Hem bekymring over et økende antall «open access»-tidsskrifter og kvaliteten på studiene som publiseres i slike tidsskrifter (1).

Vi mistenker at Hem blander sammen to aspekter ved publiserte studier, nemlig metodologisk kvalitet og nyhetsverdi. Vi trenger nemlig ikke bare de sensasjonelle studiene med positive resultater. Vi trenger også gode studier som repliserer tidligere studier, som kanskje ikke er så spektakulære, men som kan gi et riktigere bilde av problemstillingen. Forskere har dessuten juridiske og etiske forpliktelser til å gjøre forskningsresultater kjent, uavhengig av resultater. Allikevel er det vist at såkalte positive studier har nesten fire ganger så høy sjanse for å bli publisert som negative studier (2). I Tidsskriftet nr. 20/2011 viser Hem selv til saken med bevacizumab i brystkreftbehandling, og skriver at «Medikamentet ble registrert etter én overbevisende studie som viste forlenget effekt på surrogatmarkøren progredieringsfri overlevelse. Senere studier har vist mindre gevinst på slik overlevelse og ingen på samlet overlevelse» (3). Hvilke av disse studiene er «banebrytende», og hvilke er viktige for beslutningstakere i helsetjenesten?

Stadig flere finansieringskilder stiller $\mathrm{krav}$ om at resultatene fra medisinsk forskning skal være tilgjengelige for alle. Et middel i dette arbeidet er såkalte «open access»-tidsskrifter som er fritt tilgjengelige for alle på Internett. Vanligvis dekker forfatterne kostnadene ved slik publisering. Studier viser at enkeltartikler i «open access»-tidsskrifter siteres minst like ofte 